\title{
Effect of Drying Techniques and Storage Conditions on Quality and Incidence of Aflatoxins in Dried Chillies (Capsicum frutescens) in Zimbabwe
}

\author{
Muusha Linda Gamuchirai ${ }^{1 *}$, Mashingaidze Arnold Bray ${ }^{2}$ and Macheka Leslie ${ }^{2}$ \\ ${ }^{1}$ Horticulture Research Institute, Zimbabwe \\ ${ }^{2}$ Department of Crop Science and Post-Harvest, Chinhoyi University of Science and Technology, Zimbabwe \\ *Corresponding Author: Muusha Linda Gamuchirai, Horticulture Research Institute, Zimbabwe.
}

Received: April 02, 2019; Published: June 06, 2019

DOI: $10.31080 / A S A G .2019 .03 .0511$

\begin{abstract}
The export of Zimbabwean chilli is a relatively new venture as it began in 2009. In order to maintain the market share on the export market, Zimbabwean farmers have to continue producing a good quality product that is free from aflatoxin contamination or is below the maximum acceptable levels of aflatoxin contamination. Drying African Bird's' Eye in Marondera using direct sun drying $\left(35^{\circ}\right.$ to $\left.36^{\circ} \mathrm{C}\right)$, solar cabinet drying $\left(36^{\circ}\right.$ to $\left.38^{\circ} \mathrm{C}\right)$ and oven drying $\left(65^{\circ} \mathrm{C}\right)$ gave a significant difference $(\mathrm{P}<0.05)$ in total aflatoxin levels and days needed to dry the chilli. The mean total aflatoxin level for sun dried chilli was $5.67 \mathrm{ppb}$, solar cabinet dried $7 \mathrm{ppb}$, while the oven dried chilli was not contaminated. The numbers of days needed to dry chilli under direct sun (16.33 days) were significantly less than the number of days needed to dry chilli in the solar cabinet dryer (20.33 days) and from those needed in the oven dryer (1 day). The different packaging treatments used did not have a significant effect $(\mathrm{P}>0.05)$ on any of the quality parameters measured or on the total aflatoxin levels. The combined effect of drying method and packaging material did not have a significant effect on total aflatoxins, ascorbic acid content, $\mathrm{pH}$ and moisture content of the dried chilli. The packaging treatments used were hessian bags, plastic lined hessian bags, reed baskets and khaki paper bags. The incidence of aflatoxins and the quality parameters of chilli were found to be primarily affected by the drying method and not the packaging material. It is therefore important to educate and equip the farmers with the relevant skills and tools for chilli postharvest management so as to reduce the incidence of aflatoxin contamination. Keywords: Aflatoxin; African Birds Eye; Chilli; Packaging; Capsicum frutescens
\end{abstract}

\section{Abbreviations}

AFB1: Aflatoxin B1; AFB2: Aflatoxin B2; ANOVA: Analysis of Variance; BAC: Better Agriculture Company; EU: European Union; HRI : Horticulture Research Institute; IPM: Integrated Pest Control; IRC: International Rescue Committee; OTA: Ochratoxin A; SIDA: Swedish International Development Agency; Zim-Aeid: Zimbabwe Agricultural Income and Employment Development.

\section{Introduction}

The chilli (Capsicum frutescens) is a plant native to Mexico but is now being grown in many countries around the world including Zimbabwe. Chilli is used as a spice and due to its pharmacological properties it is also used in medicine [9]. Worldwide red chillies are becoming popular as they are used extensively in blended spices [6]. Chilli can also be used in the control of pests and diseases and in integrated pest control (IPM) programmes. Chilli is also a good source of vitamin A, C and E and it is also known to improve the digestive system [7].

In Zimbabwe, interest in the production of the crop is on the rise as smallholder farmers have been assisted to enter the lucrative export market of Tabasco ${ }^{\circledR}$ chillies by the Better Agriculture Company (BAC). In Zimbabwe this company is working with farmers in and around Masvingo and Chiredzi. The Tabasco ${ }^{\circledR}$ chilli project aims to improve the livelihoods of rural farming communities in Africa through sustainable business development [10]. Zimbabwean farmers are now producing Tabasco ${ }^{\circledR}$ chillies and African bird's eye chilli for both the local and export market.

Currently, Zimbabwe is ranked number 94 in world production of chilli, and the tonnage produced has increased from 100 tonnes in 1990 to 1994 tonnes in 2011 [4]. Other organisations involved in promoting chilli production in Zimbabwe include the International 
Rescue Committee (IRC), Agritex and the Swedish International Development Agency (SIDA). The Zimbabwe Agricultural Income and Employment Development (Zim-AIED) program is also assisting farmers to produce African bird's eye chilli, Tabasco ${ }^{\circledR}$ chillies and cherry peppers for export. During the period from January to March 2013, Zim-AIED assisted farmers to export 176 tonnes and 4.6 tonnes of Tabasco ${ }^{\circledR}$ chilli and African bird's' eye chilli through BAC. This produce was exported to South Africa and the European Union for further processing [5].

The EU is currently lobbying for a reduction in the maximum acceptable levels of ochratoxin A (OTA) in chillies. OTA is a mycotoxin produced by Aspergillus ochraceus, Aspergillus carbonarius and Penicillium verrucosum. The OTA limits might be reduced to $15 \mu \mathrm{g} / \mathrm{kg}$ instead of the current $30 \mu \mathrm{g} / \mathrm{kg}$. This will be effective from 1 January 2015 if the legislation passes [2]. The passing of this legislation will make it very difficult for chilli producers in tropical areas to export to the EU as their climate promotes both aflatoxin and ochratoxin development. Tropical regions are characterised by high humidity and high temperatures, conditions that favour fungal growth and mycotoxin production.

Zimbabwean chilli farmers have been availed the opportunity to enter the lucrative export market and in order to keep their market share they need to continue producing a high quality product. There is also potential to enter the European market if the required standards are met. One of the most important quality attributes for chilli is the absence of aflatoxin contamination. In the European Union, for example, the maximum acceptable level of $\mathrm{AFB}_{1}$ and total aflatoxins in red chilli is 5 and $10 \mu \mathrm{g} / \mathrm{kg}$ respectively [3].

Zimbabwean farmers therefore need to be provided with information on aflatoxin management in chilli and chilli products. Information needs to be provided on the ideal drying conditions and packaging materials that can be used in order to prevent aflatoxin contamination or to at least keep it at levels below the maximum acceptable threshold levels. Keeping in view of the mentioned facts, this study was formulated to achieve the following objectives:

- To assess aflatoxin contamination in chilli products on the local market and products destined for the export market

- To determine the effect of drying method on quality and incidence of aflatoxins on chillies

- To determine the effect of packaging material on quality and incidence of aflatoxins in chillies

\section{Materials and Methods}

The experiments were conducted at the Horticultural Research Institute (HRI) in Marondera. HRI is located at an altitude of $1630 \mathrm{~m}$ a.s.l, latitude $18^{\circ} 11^{\prime} \mathrm{S}$ and longitude $31^{\circ} 28^{\prime} \mathrm{E}$.

All the fresh chilli used for this experiment was purchased from one grower in Marondera who grows chilli for the export market. The experiment was conducted from the middle of March to the end of April which is the end of the summer season in Zimbabwe. The chilli was purchased in $15 \mathrm{~kg}$ batches of mature, red African bird's eye chilli. The experiment was replicated three times, therefore three batches were purchased. The chilli was washed using potable water making sure not to make it too wet. The $15 \mathrm{~kg}$ sample was divided into three $5 \mathrm{~kg}$ samples that were then randomly assigned to the different drying methods. The chilli used in this experiment was dried using sun drying, solar cabinet drying or oven drying. The aflatoxin levels of the chilli and the moisture content were determined before the chilli was put into the different packaging treatments.

\section{Drying methods used}

The sun drying treatment was carried out on a slanting aluminium rooftop. The chilli was spread out in a single layer and the drying was carried out from 8am to 4:30pm daily until the chilli was dry. In the evening the chilli was placed in plastic crates and stored indoors.

The oven drying treatment was done using a Genlab OV/75/SF oven. Chilli was spread out in a single layer on the shelves and was subjected to drying at a temperature of $65^{\circ} \mathrm{C}$ for 12 hours, with the oven door left partially open in order to prevent cooking.

The solar cabinet dried chilli was dried using a three shelf cabinet solar dryer model with a solar collector and a chimney. Drying was carried out from 8am to 4:30pm daily until the chilli was dry. The chilli was removed from the drier at sunset, placed in plastic crates and stored indoors overnight.

In all three treatments the chilli was dried until it obtained a crisp texture and made a rattling sound when shaken. The chilli trays were rotated regularly inside the dryer in order to ensure that the chilli dried evenly. The moisture content of the dried product was recorded. Moisture content of the chilli was measured using a moisture analyser (MOC63u, Shimadzu Moisture Analyser). The moisture analyser was set to measure moisture at a temperature of $120^{\circ} \mathrm{C}$. 
During the drying period the samples were visually checked daily for mould development. The other parameters monitored included the daily temperature readings, the number of days taken to dry each sample and the weight of the sample after the drying period. Colour changes were monitored using visual assessment.

The dried chilli sample from each drying method was then divided into four equal portions by weight, and these were randomly assigned to each packaging materials. The four packaging treatments were hessian bags, plastic lined hessian bags, khaki paper packaging and reed baskets. The control was the hessian bags. The hessian bags used measured $420 \mathrm{~mm}$ in length and $350 \mathrm{~mm}$ in diameter. The plastic lined hessian bags had a plastic layer sewn in on the inside of the bag. The khaki bags measured $330 \mathrm{~mm}$ in length and $230 \mathrm{~mm}$ in width. The reed baskets were $260 \mathrm{~mm}$ in diameter and $125 \mathrm{~mm}$ deep.

The samples were stored in the laboratory at ambient temperature. Daily recordings of temperature and humidity were taken in the laboratory. The readings were taken using a wet and dry bulb thermometer. Samples were taken at monthly intervals for a period of three months and were checked for mould development and for aflatoxin contamination.

Moisture content, $\mathrm{pH}$ and ascorbic acid content were also measured as quality parameters. Moisture content of the chilli was measured using a moisture analyser (MOC63u, Shimadzu Moisture Analyser). Moisture content was measured at $120^{\circ} \mathrm{C} . \mathrm{pH}$ was measured using a Jenway pH meter 3310. Ascorbic acid content was measured using the iodine titration method.

This experiment was set up as a $3 * 4$ factorial and the data obtained was analysed using the statistical package GenStat discovery edition 3 . The data was analysed using a two way ANOVA with randomised blocks.

\section{Results and Discussion}

The average minimum temperature recorded during the three month storage period was $15.8^{\circ} \mathrm{C}$ while the average maximum temperature was $20.9^{\circ} \mathrm{C}$. The average relative humidity was $58 \%$. During the period under which the experiment was conducted the relative humidity ranged from $55 \%$ to $60 \%$. The results obtained on the parameters measured are summarised in Table 1.

\section{Ascorbic acid content}

There was a significant effect $(\mathrm{P}<0.001)$ of drying method on ascorbic acid content of the dried chillies (Table 1). The highest ascorbic acid content was recorded with chillies dried using the solar cabinet dryer but it did not significantly differ when the chillies were sun dried. A significantly lower ascorbic acid content in the dried chillies was recorded when the chillies were oven dried than when they were dried directly in the sun or in the solar cabinet dryer. Packaging did not cause a significant interaction $(\mathrm{P}>0.05)$ in ascorbic acid concentration in the dried chillies. No significant interaction $(\mathrm{P}>0.05)$ was observed between drying method and packaging material on the ascorbic acid concentration of the chilli (Table 1).

\begin{tabular}{|c|c|c|c|c|}
\hline Treatment & $\begin{array}{c}\text { Ascorbic } \\
\text { acid content } \\
\text { mg/100g }\end{array}$ & $\begin{array}{c}\text { Moisture } \\
\text { Content } \\
\text { (\% on } \\
\text { a wet } \\
\text { basis) }\end{array}$ & pH & $\begin{array}{c}\text { Aflatoxin } \\
\text { levels } \\
\text { (ppb) }\end{array}$ \\
\hline \multicolumn{5}{|l|}{$\begin{array}{l}\text { Drying } \\
\text { Method }\end{array}$} \\
\hline Sun drying & $22^{\mathrm{a}}$ & $7.977^{\mathrm{a}}$ & $5.112^{\mathrm{a}}$ & $5^{\mathrm{a}}$ \\
\hline Oven drying & $13.58^{b}$ & $7.003^{b}$ & $4.878^{\mathrm{b}}$ & $0^{\mathrm{b}}$ \\
\hline $\begin{array}{c}\text { Solar cabinet } \\
\text { drying }\end{array}$ & $24.75^{\mathrm{a}}$ & $7.765^{\mathrm{a}}$ & $5.092^{\mathrm{a}}$ & $7.33^{\mathrm{c}}$ \\
\hline $\mathrm{p}$ - value & $<0.001$ & $<0.001$ & $<0.001$ & $<0.001$ \\
\hline l.s.d & 3.169 & 0.3586 & 0.1030 & 1.131 \\
\hline$\% \mathrm{cv}$ & 9.8 & 8.5 & 2.5 & 25.7 \\
\hline \multicolumn{5}{|l|}{$\begin{array}{c}\text { Packaging } \\
\text { Material }\end{array}$} \\
\hline Reed Basket & 19.11 & 7.761 & 5.094 & 4.22 \\
\hline $\begin{array}{c}\text { Khaki } \\
\text { Packaging }\end{array}$ & 18.72 & 7.729 & 4.989 & 4.11 \\
\hline Hessian bag & 20.39 & 7.538 & 4.988 & 4 \\
\hline $\begin{array}{l}\text { Plastic lined } \\
\text { hessian bag }\end{array}$ & 22.22 & 7.299 & 5.037 & 4.11 \\
\hline $\mathrm{p}$ - value & 0.218 & 0.109 & 0.230 & 0.988 \\
\hline l.s.d & 3.659 & 0.4141 & 0.1189 & 1.306 \\
\hline$\% \mathrm{cv}$ & 9.8 & 8.5 & 2.5 & 25.7 \\
\hline \multicolumn{5}{|c|}{ Drying method $x$ packaging material interaction } \\
\hline $\mathrm{p}$ - value & 0.221 & 0.830 & 0.415 & 0.963 \\
\hline l.s.d & ns & ns & ns & ns \\
\hline$\% c \mathrm{cv}$ & 18.6 & 5.6 & 2.4 & 32.5 \\
\hline
\end{tabular}

Table 1: Effect of drying method and packaging material on quality parameters and aflatoxin levels in chilli. 


\section{Moisture content}

The different drying methods produced a significant effect $(\mathrm{P}<0.001)$ on the moisture content of the dried chillies. The highest moisture content was recorded when the chillies were dried directly in the sun but it did not significantly differ to when the chillies were dried in the solar cabinet dryer. The moisture content recorded when the chillies were oven dried was significantly lower than when the chillies were dried directly under the sun or in the solar cabinet dryer. Packaging did not cause a significant interaction $(\mathrm{P}>0.05)$ in moisture content of the dried chillies. No significant interaction was observed between drying method and packaging material on the moisture content of the chilli (Table 1).

\section{$\mathrm{pH}$}

There was a significant effect $(\mathrm{P}<0.001)$ of drying method on the $\mathrm{pH}$ of the dried chillies. Sun dried chillies recorded the highest $\mathrm{pH}$ but it did not significantly differ when the chillies were dried in the solar cabinet dryer (Table 1). A significantly lower $\mathrm{pH}$ was recorded when the chillies were oven dried than when they were dried directly under the sun or in the solar cabinet dryer. Packaging did not cause a significant interaction $(\mathrm{P}>0.05)$ in $\mathrm{pH}$ of the dried chillies. No significant interaction $(\mathrm{P}>0.05)$ was observed between drying method and packaging material on the $\mathrm{pH}$ of the dried chillies (Table 1).

\section{Aflatoxins}

The different drying methods produced a significant effect $(\mathrm{P}<0.001)$ in the total aflatoxin levels of the dried chillies after three months in storage. The highest aflatoxin level was recorded in the chillies that were dried using the solar cabinet dryer and these were significantly different to the total aflatoxin levels recorded when the chillies were dried directly under the sun (Table 1). No aflatoxins were recorded in the oven dried chillies. Packaging did not cause a significant interaction $(P>0.05)$ in total aflatoxin levels of the dried chillies. No significant interaction $(\mathrm{P}>0.05)$ was observed between drying method and packaging material on the total aflatoxin levels of the chillies (Table 1).

\section{Effect of time in storage}

There was no interaction observed between time in storage and packaging material on moisture content, $\mathrm{pH}$ and ascorbic acid content. However as the time in storage increased up to 3 months there were significant differences observed in the moisture content, $\mathrm{pH}$ and ascorbic acid content of the chilli. Interaction between time in storage and drying method used produced a significant difference $(P<0.001)$ for moisture content and for ascorbic acid content $(\mathrm{P}<0.007)$. Research done in India showed that biochemical constituents of cold stored chilli such as ascorbic acid decrease gradually with increasing time in storage (8). This agrees with the results obtained in this study which also showed a gradual decrease in ascorbic acid content. A similar interaction was observed for $\mathrm{pH}$.

As time in storage increased the moisture content increased up to the second month in storage. After three months in storage the moisture content had gone down. A similar trend was observed for all the packaging treatments utilised. These trends are shown in Figure 1 and Figure 2. This low moisture content could be the reason why the aflatoxin levels did not increase. Foods with low moisture content generally have a low water activity (aw) which is a measure of the amount of free water in a food that can support the growth of moulds and bacteria. Water content and water activity have a nonlinear relationship that shows that at a given temperature and pressure as water activity increases the water content also increases [11]. Research done on the Ethiopian red chilli variety 'Mareko fana', on moisture sorption isotherms revealed the relationship between moisture content and water activity [11].

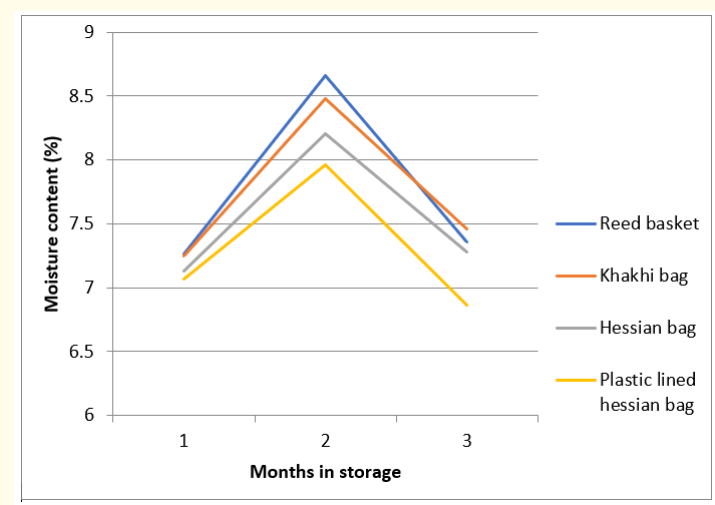

Figure 1: Change of moisture content with increasing time in storage.

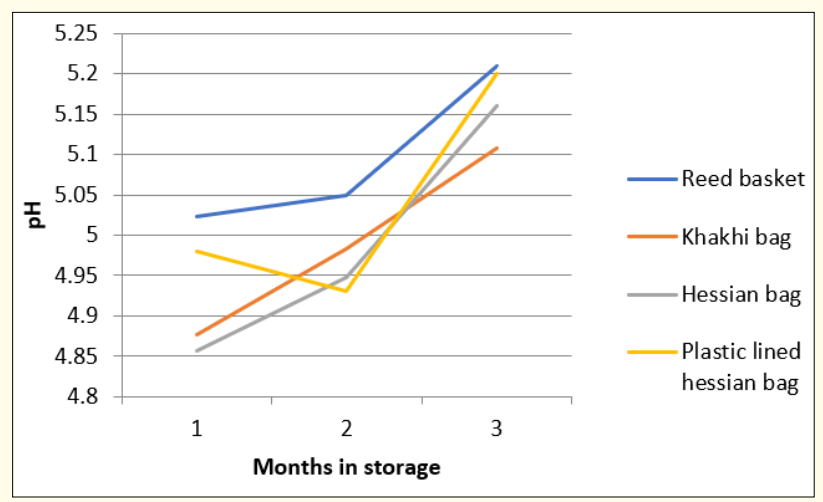

Figure 2: Change of $\mathrm{pH}$ with increasing time in storage. 
Using that data it can be suggested that at the low moisture content that the chilli was dried to $(4.4 \%$ for oven dried chilli), the water activity was low enough to prevent the colonisation of the chilli by the fungi. The solar dried ( $5 \%$ moisture content) and the sun dried chilli (4.3\% moisture content) were contaminated during drying but the water activity was then reduced to a point where it inhibited the further development of the Aspergillus flavus. The different packaging materials maintained the moisture content at levels that were low enough to inhibit aflatoxin production.

The aflatoxin levels did not change significantly over the three month storage period. This could be explained by the temperature and humidity conditions under which the chilli was stored. The average minimum temperature recorded was $15.8^{\circ} \mathrm{C}$ while the average maximum temperature was $20.9^{\circ} \mathrm{C}$. The average relative humidity was $58 \%$. Aflatoxin contamination is favoured by warm humid conditions. It has been proven that aflatoxin causing fungi do not favour cool climates [1], and this could be why the dried chilli that was stored when it was aflatoxin free did not get contaminated during storage.

\section{Conclusion}

No interaction between drying method and packaging material was found for all the quality parameters analysed. This means that under the storage conditions experienced during the three month period the different packaging materials did not affect the quality attributes. The quality attributes were determined by the drying method used and all the packaging materials managed to maintain those attributes in a similar manner.

It can therefore be concluded that under the cool climatic conditions experienced in Marondera, African bird's eye chilli should be oven dried in order to avoid aflatoxin contamination. When stored under cool, dry conditions dried chilli can be safely stored in reed baskets, plastic lined hessian bags, hessian bags or khaki packaging for up to three months without becoming contaminated with aflatoxins.

\section{Bibliography}

1. Cotty PJ and Jaime-Garcia R. "Influences of climate on aflatoxin producing fungi and aflatoxin contamination". International Journal of Food Microbiology 119.1-2 (2007): 109-115.
2. Crem BV and Koekoek FJ. CBI Product Factsheet: Chillies in the EU. CBI market information database. (2014).

3. European Commission Regulation (ECR).2010. (EC No. 165/2010 of 26 February 2010) Amending regulation (EC) No 1881/2006. Setting maximum levels for certain contaminants in foodstuffs as regards aflatoxins". Official Journal of the European Union 50(2010): 8-12.

4. Factfish. "Chillies and Peppers, green production quantity for Zimbabwe". (2013).

5. Fintrac. Smallholder Market News: January-March (2013).

6. Khan MA., et al. "Reduction of aflatoxins in Dundi-cut whole red chillies (Capsicum indicum) by manual sorting technique". Science Technology and Development 32.1 (2013): 16-23.

7. Pawar SS., et al. "Chillies as food, spice and medicine: A Perspective". International Journal of Pharmacy and Biological Sciences 1.3 (2011): 311-318.

8. Ravikiran D., "Mold associated biochemical changes and aflatoxin B1 production in cold stored chillies (Capsicum annum L.)". Journal of Food processing and Preservation 33. S1 (2009): $203-213$

9. Reyes-Escogido ML., et al "Chemical Pharmacological Aspects of Capsaicin". Molecules 16.2 (2011): 1253-1270.

10. Salinas PS. “Cultivation, processing of chillies into chilli mash for export (Mozambique). (2010).

11. Seid RM and Hensel O. "Experimental evaluation of sorption isotherms of chili pepper: an Ethiopian variety, Mareko fana (Capsicum annum L.)". Agricultural Engineering International CIGR Journal 14.4 (2012): 163-172.

\section{Volume 3 Issue 7 July 2019 (C) All rights are reserved by Muusha Linda Gamuchirai.}

